\title{
Seasonal variations and vertical features of aerosol particles in the Antarctic troposphere
}

\author{
K. Hara ${ }^{1, *}$, K. Osada ${ }^{2}$, C. Nishita-Hara ${ }^{2, * *}$, and T. Yamanouchi ${ }^{1}$ \\ ${ }^{1}$ National Institute of Polar Research, Tokyo, Japan \\ ${ }^{2}$ Graduate School of Environmental Studies, Nagoya University, Nagoya, Japan \\ *now at: Department of Earth System Science, Faculty of Science, Fukuoka University, Fukuoka, Japan \\ ** now at: Advances Materials Institute, Fukuoka University, Fukuoka, Japan
}

Received: 7 February 2011 - Published in Atmos. Chem. Phys. Discuss.: 4 March 2011

Revised: 18 May 2011 - Accepted: 20 May 2011 - Published: 15 June 2011

\begin{abstract}
Tethered balloon-borne aerosol measurements were conducted at Syowa Station, Antarctica during the 46th Japanese Antarctic expedition (2005-2006). The CN concentration reached a maximum in the summer, although the number concentrations of fine particles $\left(D_{p}>0.3 \mu \mathrm{m}\right)$ and coarse particles $\left(D_{p}>2.0 \mu \mathrm{m}\right)$ increased during the winterspring. The $\mathrm{CN}$ concentration was $30-2200 \mathrm{~cm}^{-3}$ near the surface (surface $-500 \mathrm{~m}$ ) and $7-7250 \mathrm{~cm}^{-3}$ in the lower free troposphere $(>1500 \mathrm{~m})$. During the austral summer, higher $\mathrm{CN}$ concentration was often observed in the lower free troposphere, where the number concentrations in fine and coarse modes were remarkably lower. The frequent appearance of higher $\mathrm{CN}$ concentrations in the free troposphere relative to continuous aerosol measurements at the ground strongly suggests that new particle formation is more likely to occur in the lower free troposphere in Antarctic regions. Seasonal variations of size distribution of fine-coarse particles show that the contribution of the coarse mode was greater in the winterspring than in summer because of the dominance of sea-salt particles in the winter-spring. The number concentrations of fine and coarse particles were high in air masses from the ocean and mid-latitudes. Particularly, aerosol enhancement was observed not only in the boundary layer, but also in the lower free troposphere during and immediately after Antarctic haze events occurring in May, July and September.
\end{abstract}

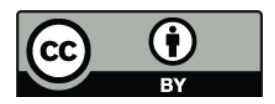

Correspondence to: K. Hara (harakei@fukuoka-u.ac.jp)

\section{Introduction}

Atmospheric aerosol particles are closely related to climate change through direct and indirect effects (e.g., IPCC, 2007). Compared to the Arctic, the Antarctica is isolated from human activities on the other continents. This isolated situation of the Antarctic region causes a lower number density of aerosol particles relative to the other regions (e.g., Ito, 1989). Because of the low aerosol number concentration, aerosol direct effects can be negligible in Antarctic regions (Bodhaine, 1995). The contribution of the indirect effect of coupling with aerosols and bioactivity in the ocean has been discussed for Antarctic regions for several decades (Shaw, 1983; Charlson et al., 1987; Meskhidze and Nenes, 2006; Ayers and Cainey, 2007).

Aerosol measurements in Antarctic regions have been made at coastal stations: Syowa $\left(69^{\circ} 00^{\prime} \mathrm{S}\right.$ and $39^{\circ} 35^{\prime} \mathrm{E}$ )(Ito et al., 1989, 1993; Osada et al., 1998; Hara et al., 2004, 2010), Halley $\left(75^{\circ} 36^{\prime} \mathrm{S}, 26^{\circ} 19^{\prime} \mathrm{W}\right.$ ) (Wolff et al.,1998; Rankin and Wolff, 2003), Neumayer $\left(70^{\circ} 39^{\prime} \mathrm{S}, 08^{\circ} 15^{\prime} \mathrm{W}\right)$ (Wagenbach et al., 1998; Minikin et al., 1998), Dumont d'Urville $\left(66^{\circ} 40^{\prime} \mathrm{S} ; 140^{\circ} 00^{\prime} \mathrm{E}\right)$ (Legrand et al., 2001), and Mawson $\left(67^{\circ} 36^{\prime} \mathrm{S} 62^{\circ} 52^{\prime} \mathrm{E}\right)$ (Savoie et al., 1992, 1993). They have also been made at inland stations: Dome-F $\left(77^{\circ} 19^{\prime} \mathrm{S} 39^{\circ} 42^{\prime} \mathrm{E}\right)$ (Hara et al., 2004), Kohnen $\left(75^{\circ} 00^{\prime} \mathrm{S}\right.$ $\left.00^{\circ} 04^{\prime} \mathrm{E}\right)$ (Weller et al., 2007), Concordia $\left(75^{\circ} \mathrm{S}, 123^{\circ} \mathrm{E}\right)$ (Jourdain et al., 2008), and at the South Pole (Amundsen Scott) $\left(90^{\circ} \mathrm{S}\right)$ (Bodhaine, 1995). Some investigations have pointed out the likelihood of aerosol transport through the free troposphere (e.g., Hara et al., 2006) and new particle formation in the free troposphere (Ito et al., 1993; Koponen et al., 2002). Recent works suggested that black carbon,

Published by Copernicus Publications on behalf of the European Geosciences Union. 
derived mostly from biomass burning, was transported to Antarctic coasts (Fiebig et al., 2009; Hara et al., 2010). Significant increase of anthropogenic species, however, have not been identified in the Antarctic ice core records (e.g., Legrand and Mayewski, 1997; Watanabe et al., 2003; Kaufmann et al., 2010) and snow pit record (Iizuka et al., 2004). Furthermore, our previous investigation showed the occasional occurrence of Antarctic haze at Syowa Station during winter-spring (Hara et al., 2010). With developing human activity and industrialization in the Southern Hemisphere in the future, more anthropogenic species can be transported to the Antarctic regions. Most of aerosol observations, however, were conducted on the ground surface because of severe conditions and limitations of logistic works in Antarctic regions.

Previous aerosol measurements in the upper atmosphere of Antarctic regions were conducted using (1) airplanes (Iwasaka et al., 1985; Yamazaki et al., 1989; Yamanouchi et al., 1999; Wada et al., 2001; Hara et al., 2006; Osada et al., 2006), (2) balloon-borne particle counters (i.e., aerosol sonde) (Ito et al., 1986; Hayashi, 2001), and (3) tethered balloons (Rankin and Wolff, 2002). These previous works indicated (1) aerosol enhancement in free troposphere immediately after cyclone passing (Yamanouchi et al., 1999), (2) appearance of a $\mathrm{CN}$-enhanced layer in lower free troposphere (Osada et al., 2006), and (3) transport of sea-salt particles and mineral particles from mid-latitudes through the free troposphere (Yamazaki et al., 1989; Hara et al., 2006). Vertical and seasonal distributions of the aerosol number concentration and constituents in the upper atmosphere, however, are poorly known for Antarctic regions because aerosol measurements in the free troposphere over Antarctica are limited. Thus, the lack of knowledge prevents the quantification of contribution of aerosols to the Antarctic climate. Therefore, aerosol measurements in the free troposphere must be done simultaneously with those at ground level to elucidate aerosol properties (e.g., number concentrations and constituents), aerosol-related processes (e.g., transport processes, heterogeneous reactions and cloud interaction) in Antarctic regions and roles of aerosols in the Antarctic climate.

Airplane-borne aerosol measurements have a distinct advantage in payload: many aerosol properties can be measured simultaneously. The severe logistics preparation and large costs, however, are necessary for such operations. Launched balloon-borne aerosol measurements can provide vertical features of aerosol number concentration in a wide vertical range (surface-stratosphere). Because the recovery of the aerosol instruments and samples for chemical analysis are difficult and occasionally dangerous to obtain in Antarctic regions, only radio-transmissive data (e.g., number concentration) are obtained in the launched balloon-borne aerosol measurements. Tethered balloon-borne aerosol measurements can easily and safely obtain aerosol samples and the number concentrations, although the observable altitude is re- stricted by the winch-line length and wind speed. Tetheredballoon systems were used for aerosol measurements in the lower troposphere (surface - lower free troposphere) in this study. Consequently, the present study was undertaken to elucidate the vertical and seasonal features of aerosol physicochemical properties in the Antarctic troposphere from yeararound tethered balloon-borne aerosol measurements. Here, we discuss mainly (1) seasonal and vertical distributions of aerosols, (2) new particle formation events in the upper atmosphere, and (3) vertical structures of Antarctic haze.

\section{Measurements}

A tethered-balloon was applied to aerosol measurements to ascertain vertical features of aerosol number concentrations and aerosol constituents in the lower troposphere. Instruments for the tethered balloon system and aerosol measurements are presented in Table 1. Tethered-balloon (TTB-329; Vaisala) and tether line (TTL-324; Vaisala) were used for the operation. The tethered balloon was made of urethane film. The balloon size and payload were, respectively, $5.2 \mathrm{~m}$ long, $2.3 \mathrm{~m}$ in diameter, and ca. $5.5 \mathrm{~kg}$. A hand-held type condensation particle counter (CPC: 3007; TSI Inc.) was used to measure the concentration of condensation nuclei $(\mathrm{CN})$ larger than $10 \mathrm{~nm}$ diameter. A portable optical particle counter with six size channels (OPC: KR-12A; Rion Co. Ltd.) was used to obtain the number concentration and size distribution of aerosol particles larger than $0.3 \mu \mathrm{m}$ in diameter. The sampling resolution was adjusted to $1 \mathrm{~s}$ in CPC and ca. $23 \mathrm{~s}$ (every 11) in OPC. Aerosol data were recorded by built-in data loggers in CPC and OPC, and were downloaded after the measurements. Meteorological data (pressure, temperature, relative humidity, wind direction and wind speed) were obtained using tether-sonde (Tether sonde, TTS-111; Vaisala). Because aerosol measurements were made at lower temperatures, the CPC, OPC and aerosol impactor were installed into insulator boxes during the measurements. A few disposable heating pads (commercial products of Japan) were installed in the insulator boxes to keep warm condition. The temperature in the box was monitored by thermo sensor equipped in the OPC (KR12A). Even in the coldest condition (ca. $-34{ }^{\circ} \mathrm{C}$ ), the temperature in the box was higher than $2-3{ }^{\circ} \mathrm{C}$ during the measurements. The ca. $5 \mathrm{~cm}$ length conductive tubes were set to the inlet of CPC and OPC to take in ambient air. The insulator box was fixed ca. $30 \mathrm{~m}$ below the balloon. The tether sonde was fixed on the tether line less than 2-3 $\mathrm{m}$ from the aerosol instruments. Considering the temperature difference between ambient air and the inside of the insulator box, the number concentration might be measured mostly under the dry conditions. CN concentration and OPC data taken by tethered balloon system was well matched to the $\mathrm{CN}$ concentration and OPC data obtained by ground-base monitoring in the "clean air observatory" at Syowa station. 
Table 1. List of equipment and instruments for tethered-balloon borne aerosol measurements at Syowa Station, Antarctica.

\begin{tabular}{|c|c|c|c|}
\hline Instrument & Type & Manufacturer & Memo \\
\hline Tethered balloon & TTB-329 & Vaisala & Payload ca. $5.5 \mathrm{~kg}$ \\
\hline Electric winch & TTW-111 & Vaisala & \\
\hline Tether line & $\begin{array}{l}\text { TTL-324 } \\
(240 \# 3 \mathrm{~km})\end{array}$ & Vaisala & Length, $3000 \mathrm{~m}$ \\
\hline Tether sonde & TTS-111 & Vaisala & $\begin{array}{l}\text { Sensor was changed } \\
\text { periodically. }\end{array}$ \\
\hline Data receiver & SPS-220T & Vaisala & \\
\hline Condensation particle counter & CPC-3007 & TSI & $\begin{array}{l}\text { Measurable size, } D_{p}>10 \mathrm{~nm} \\
\text { Flow rate, } 0.71 \mathrm{~min}^{-1}\end{array}$ \\
\hline Optical particle counter & KR-12A & RION & $\begin{array}{l}\text { Measurable size, } D_{p}>0.3,0.5 \\
0.7,1.0,2.0 \text {, and } 5.0 \mu \mathrm{m} \\
\text { Flow rate, } 2.831 \mathrm{~min}^{-1}\end{array}$ \\
\hline 2-stage aerosol impactor & Custom made & ARIOS & $\begin{array}{l}\text { Cut-off diameter, } 0.2 \text { and } 2.0 \mu \mathrm{m} \\
\text { Flow rate, } 1.201 \mathrm{~min}^{-1}\end{array}$ \\
\hline Command receiver for impactor & Custom made & Sky remote & \\
\hline Radio controller for impactor & NET J120HS & $\begin{array}{l}\text { Japan Remote } \\
\text { Control }\end{array}$ & Wavelength, $72 \mathrm{MHz}$ \\
\hline
\end{tabular}

Tethered balloon operation was conducted at the Cheliport of Syowa Station, Antarctica $\left(69^{\circ} 00^{\prime} \mathrm{S}, 39^{\circ} 35^{\prime} \mathrm{E}\right)$ on east Ongul Island. East Ongul Island is located in Lutzow Holm bay and lies ca. $4 \mathrm{~km}$ away from the Prince Olav coast of the Antarctic continent. The distance from Syowa station and sea-ice margin was approximately $100 \mathrm{~km}$ during the summer and $1000 \mathrm{~km}$ during the winter-spring. The C-heliport (ca. $15 \mathrm{~m}$ in GPS altitude) is located windward of the prevailing winds and ca. $600 \mathrm{~m}$ distant from the main area which has a diesel power station. For safe operation, tethered-balloon-borne aerosol measurements were made under conditions with weaker surface winds (mean $<5 \mathrm{~m} \mathrm{~s}^{-1}$ ). In the case of strong winds $\left(>12 \mathrm{~m} \mathrm{~s}^{-1}\right)$ in the upper atmosphere, the balloon stopped ascending and then descended to avoid breakage of the tether-line and balloon. When thick clouds appeared at the observable altitude over Syowa Station, the measurements stopped around the cloud base. In the case of thin clouds, the aerosol measurements were continued above the clouds. Because the tethered-balloon operation was restricted by surface wind conditions, tethered balloon borne aerosol measurements was done one to three times a month. In this study, we classified "lower troposphere (observed range)" into the surface inversion layer (ca. $<300 \mathrm{~m}$ ), boundary layer (ca. $1000 \mathrm{~m}$ ), and lower free troposphere (ca. $>1000 \mathrm{~m}$ ) according to vertical features of air temperature (e.g., temperature inversion) and relative humidity in each tethered balloon measurement.

Figure 1 depicts a typical example of the balloon trajectory during the aerosol measurements. Speeds of ascent and descent were adjusted to approximately $1 \mathrm{~m} \mathrm{~s}^{-1}$ in each tethered balloon-borne measurement. Measurements using $\mathrm{CPC} / \mathrm{OPC}$ and direct aerosol sampling were operated inde- pendently because of payload limitations. In the first operation, the aerosol number concentration and meteorological parameters were measured using $\mathrm{CPC}$, OPC and tethersonde. Second, direct aerosol sampling was conducted using an aerosol impactor and tether-sonde. Aerosol samples were taken at several levels (depending on the highest altitude), which were chosen based on vertical profiles of air temperature and relative humidity. The sampling time was $10-15 \mathrm{~min}$ for one sample. Here, we specifically examine vertical and seasonal variations of aerosol number concentrations and the size distribution. Vertical and seasonal variations of aerosol constituents and mixing states will be discussed elsewhere. The aerosol number concentrations were converted to those under the standard condition $\left(0^{\circ} \mathrm{C}\right.$ and $\left.1013 \mathrm{hPa}\right)$.

\section{Results and discussion}

\subsection{Air mass history}

The air mass history is important for understanding transport processes, sources and sinks of aerosols. To compare air mass history and aerosol data, the five-day backward trajectory was computed from heights of 100-2500 m (every $100 \mathrm{~m}$ ) above ground level over Syowa Station using vertical motion mode in the NOAA-HYSPLIT model with "NCEP reanalysis" data (Draxler and Rolph, 2011). A pattern of backward trajectory was classified into transport from (1) the Southern Ocean, (2) Antarctic coasts, and (3) Antarctic continent (inland). The highest and lowest latitudes, during a five-day backward trajectory, are shown in Fig. $2 b$ and c. The lowest latitudes of the air mass at altitudes lower than $1000 \mathrm{~m}$ were distributed mostly in $>65^{\circ} \mathrm{S}$, as presented in 


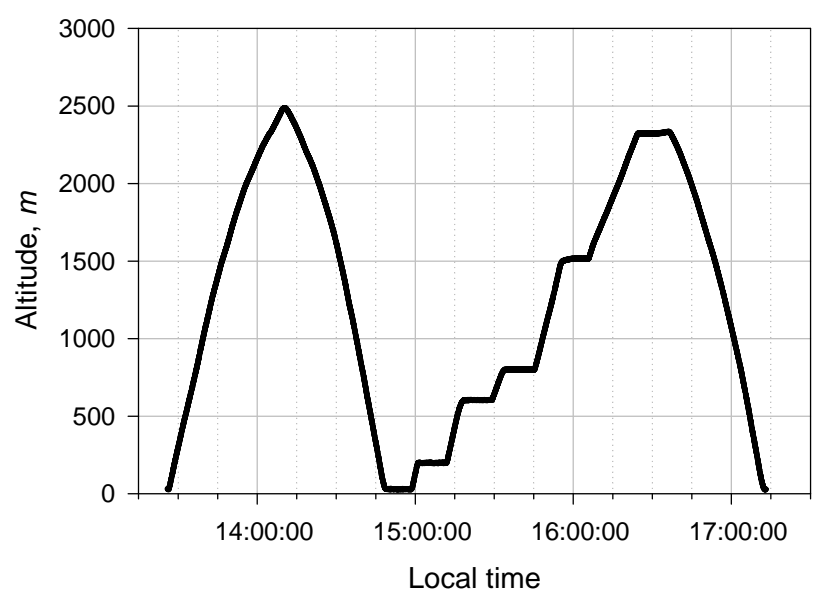

Fig. 1. Typical balloon trajectory.

Fig. 2b. Therefore, air masses at a lower level $(<1000 \mathrm{~m})$ might be transported through the Antarctic coast and continent in many cases. Transport from the Southern Ocean was often identified at altitudes higher than $1000 \mathrm{~m}$, for example on 12 February 2005 and 28 May 2005. In particular, air masses at $800-1000 \mathrm{~m}$ on 28 May 2005 were transported from the mid-latitudes (ca. $\left.38^{\circ} \mathrm{S}\right)$. The variation of the highest latitudes during the trajectory indicates that the transport of continental air $\left(75-80^{\circ} \mathrm{S}\right)$ to Syowa Station was recognized mostly at $<1500 \mathrm{~m}$ altitude.

The highest and lowest altitudes during the five-day backward trajectory are shown in Fig. $2 d$ and e. Because tethered balloon operations were conducted under calm weather conditions in high air pressure, downward transport from the upper troposphere over the continent was often observed as presented in Fig. 2d, when air masses over the Antarctic continent came over Syowa Station. For instance, the air mass in the upper troposphere $(>4000 \mathrm{~m}$ ) over Antarctic coast to the continent was transported to the boundary layer $(<1000 \mathrm{~m})$ over Syowa Station during 28 June 2005. In contrast, the air mass in the upper atmosphere $(>1000 \mathrm{~m})$ over Syowa Station came from the lower altitudes, as presented in Fig. 2e. The air mass in the boundary layer over the Southern Ocean was transported into the free troposphere over Syowa Station (e.g., 1 August).

\subsection{Seasonal and vertical variation of aerosol number concentration}

\subsubsection{Variation of coarse and fine particles}

In general, the aerosol concentration was influenced considerably by local contamination. The icebreaker Shirase (vessel) and helicopters operated around Syowa Station for logistic and scientific work from end-December until early February. Helicopters were operated usually below ca. $70 \mathrm{~m}$ $(200 \mathrm{ft})$ above ground level. Furthermore, no helicopter op-
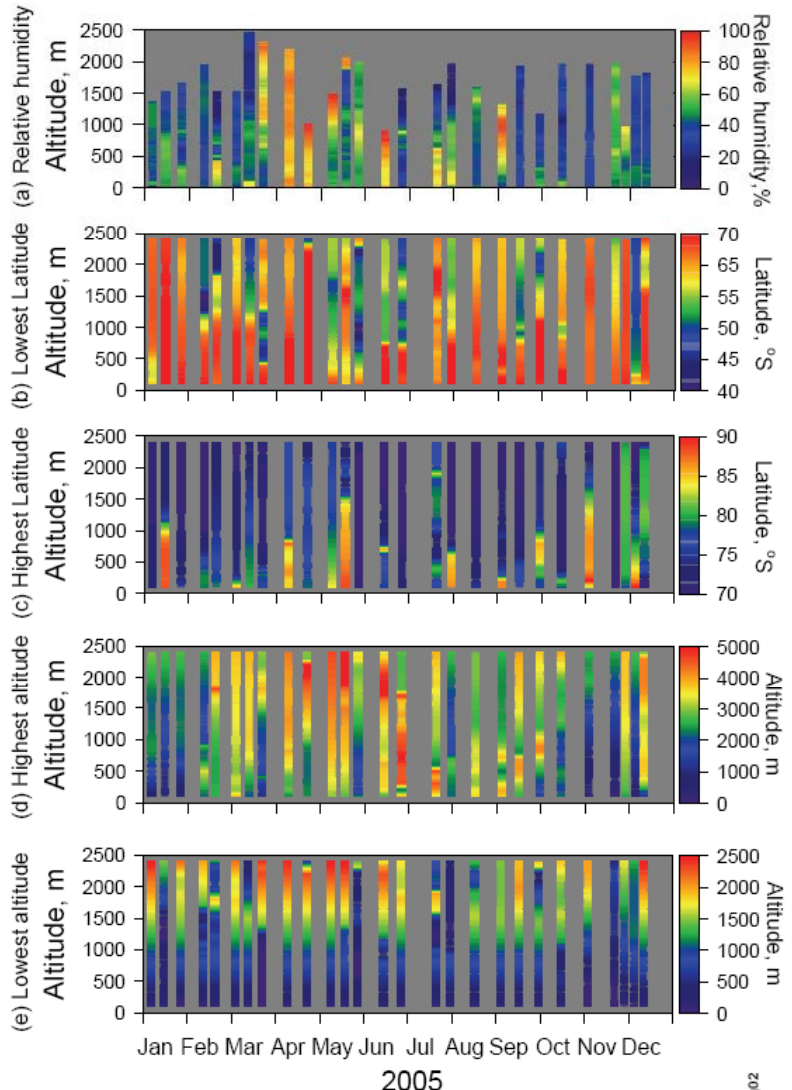
2005

Fig. 2. Seasonal and vertical features of relative humidity and air mass history at Syowa Station, Antarctica: (a) relative humidity, (b) the lowest latitude in 5-day backward trajectory, (c) the highest latitude, (d) the highest altitude, and (e) the lowest altitude. Relative humidity was measured by tetheresonde. Y-axis height means start altitude in the trajectory and colour contour indicates air mass history calculated in the trajectory.

erated during the summer. Although Syowa Station was a strong contamination source itself, vertical mixing might be insufficient to lift contaminated air on the ground up to the free troposphere. The aerosol number concentrations around ground level at the C-heliport (tethered balloon) were well matched to those at "clean air observatory (ground-base measurement site). In addition, aerosol concentrations near the surface during the tethered balloon operation show an insignificant increase owing to local contamination, so that we can conclude that the aerosol concentrations taken by tethered balloon-borne measurements were unaffected by local contamination.

Figure 3 shows seasonal and vertical features of relative humidity and the aerosol number concentration. The number concentrations of fine $\left(D_{p}>0.3 \mu \mathrm{m}\right)$ and coarse $\left(D_{p}>\right.$ $2.0 \mu \mathrm{m})$ particles in the lower troposphere were high in the winter and lower in the summer. The range of number concentrations in fine and coarse modes in the boundary layer 

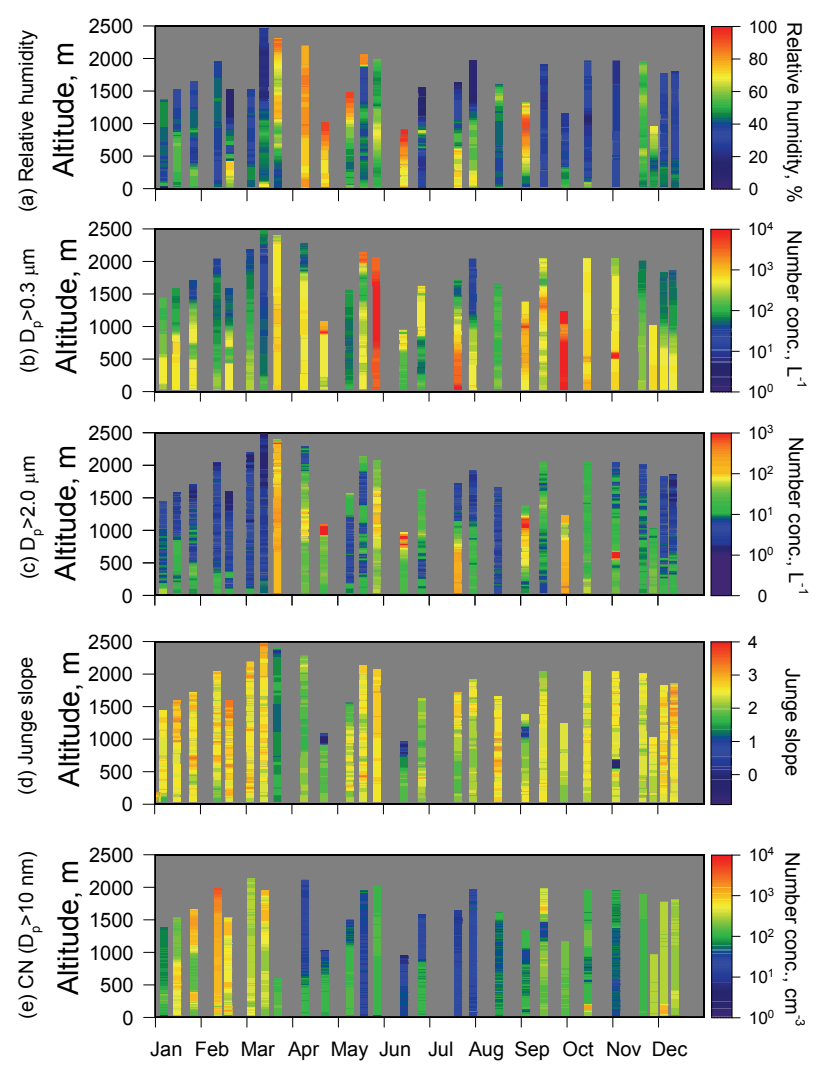

2005

Fig. 3. Seasonal and vertical features of (a) relative humidity, (b) the number concentration of aerosols $\left(D_{p}>0.3 \mu \mathrm{m}\right)$, (c) the number concentration of aerosols $\left(D_{p}>2.0 \mu \mathrm{m}\right)$, (d) Junge slope, and (e) CN concentration, at Syowa Station, Antarctica.

were $340-1.2 \times 10^{4} 1^{-1}$ (mean, $10871^{-1}$; median, $12371^{-1}$ ) and $0.9-4301^{-1}$ (mean, $30.61^{-1}$; median, $13.41^{-1}$ ), respectively. In contrast, ground-base aerosol measurements using OPC at Syowa in 2005 showed a range of $198-2.0 \times 10^{5} 1^{-1}$ (mean, 89461 $1^{-1}$; median, $35351^{-1}$ ) in fine mode and $0.8-$ $36291^{-1}$ (mean, $1171^{-1}$; median, 65.41 $1^{-1}$ ) in coarse mode (Osada et al., 2010a). Higher concentrations in the groundbase measurements, relative to that in the tethered balloon measurements, might result from the increase of the number concentrations under storm conditions. The seasonal variation in the tethered balloon measurements, however, showed a good agreement with the continuous aerosol measurement near the surface at Syowa Station in 2005 (Osada et al., 2010a) and past (e.g., Ito et al., 1989, 1993). Aerosol concentrations in the winter-spring increased clearly under the storm conditions resulting from the cyclone approach (e.g., Ito, 1989; Hara et al., 2004, 2010, 2011). Because aerosol particles were composed predominantly of sea-salts (e.g., $\mathrm{Na}^{+}$and $\mathrm{Cl}^{-}$) during winter-spring (Hara et al., 2004, 2010, 2011), the number concentrations in the Antarctic coast during winter-spring might be associated with emission and transport of sea-salt particles from the ocean and sea-ice areas. In contrast to the winter-spring, storm conditions at- tributable to a cyclone approach are not frequent in the summer (Sato and Hirasawa, 2007), so that insufficient sea-salt emission might result in a lower concentration in fine and coarse particles in the summer. Indeed, the concentration of sea-salt particles was lower during the summer at Syowa Station (Hara et al., 2004).

Aerosol number concentrations of coarse and fine particles were lower in the free troposphere $(>1200 \mathrm{~m})$ than those in the boundary layer $(<1000 \mathrm{~m})$. The mean concentration of fine particles $\left(D_{p}>0.3 \mu \mathrm{m}\right)$ was in the order of $10^{3} 1^{-1}$ in the boundary layer and order of $10^{2} 1^{-1}$ in the free troposphere during the summer, whereas it was in the order of $10^{3} 1^{-1}$ (maximum $>10^{4} 1^{-1}$ ) near surface and in free troposphere during the winter. However, the number concentration of coarse particles $\left(D_{p}>2.0 \mu \mathrm{m}\right)$ ranged from $1-1001^{-1}$ in the free troposphere and 4-200 $1^{-1}$ in the boundary layer during the winter, and $<101^{-1}$ in the free troposphere and $2-301^{-1}$ in the boundary layer during the summer. As described above, aerosol enhancement during winter was obtained during transport from the Southern Ocean and the Antarctic coast. Previous air-borne aerosol measurements by Yamanouchi et al. (1999) suggested considerable aerosol enhancement in the free troposphere immediately after passing of a cyclone. Consequently, the poleward flow from the mid-latitudes and vertical mixing of aerosols by a cyclone approach might enhance the higher aerosol concentration even in the free troposphere during winter-spring.

For the comparison of the aerosol size distribution, the Junge-slope was estimated in this study. The size distribution of fine-coarse particles can be approximated using the following equation (Junge, 1963);

$\frac{d N}{d \log D_{p}}=\alpha e^{-\beta}$,

where $\alpha$ and $\beta$, respectively, stand for a constant and Jungeslope. Here, the Junge-slope $(\beta)$ was estimated in the size range of $0.3-5.0 \mu \mathrm{m}$ in diameter. When the number concentration of coarse particles is lower or that of fine particles is higher, $\beta$ can be a higher value. As shown in Fig. 3d, negative values of $\beta$ were observed at altitudes with cloud appearance on 23 April, 16 June, 4 September and 3 November. The negative values might result from higher concentration in coarse mode because of cloud activation. With the exception of the cloud layer $(\beta<0), \beta$ was $1.5-3.0$ over Syowa Station. The range of $\beta$ in this study was slightly lower than that $(\beta: 1.6$ 5.3) observed at altitudes lower than $2500 \mathrm{~m}$ using an airplane (Osada et al., 2006). This difference might result from the underestimation of the number concentration of coarse particles in airplane-borne aerosol measurements because the high speed of airplanes and the long-tube between inlet and OPC can engender significant losses of coarse particles.

In the lower free troposphere $(>1200 \mathrm{~m}), \beta$ was $2.2-$ 3.2 (median $\beta=2.5$ ) in summer-autumn (January-March and December) and 1.5-2.8 (median $\beta=2.4$ ) in winterspring (April-November), whereas $\beta$ in the boundary layer 
was 2.2-2.7 (median $\beta=2.5$ ) in summer-autumn (JanuaryMarch and December) and 1.7-2.4 (median $\beta=2.2$ ) in winter-spring (April-November). Because of the vertical gradient of the number concentration of coarse particles, $\beta$ in the boundary layer tended to be lower than that in the free troposphere. The marked contrast of $\beta$ between the summer and winter is likely to be related to major aerosol constituents and their size distribution. In the austral summer, major aerosol constituents are $\mathrm{CH}_{3} \mathrm{SO}_{3}^{-}$and non-seasalt (nss-) $\mathrm{SO}_{4}^{2-}$ which are distributed in ultra-fine and fine particles and which are derived from bioactivity in the ocean (e.g., Ito, 1993; Minikin et al., 1998). Meanwhile, sea-salt particles are dominant on the Antarctic coast in the winter (Hara et al., 2004, 2005, 2010). High concentrations of $\mathrm{CH}_{3} \mathrm{SO}_{3}^{-}$and nss- $\mathrm{SO}_{4}^{2-}$ and low concentration of sea-salt particles in the summer can engender higher $\beta$, and vice versa in the winter. Although $\beta$ was usually lower in the winter, $\beta$ occasionally dropped to $<2$ even in the autumnspring (23 March, 10 April, 23 April, 16 June, 22 July, and 4 September) when diamond dust or conditions of higher relative humidity were observed. Air masses with lower $\beta$ value were transported from ocean and the Antarctic coast, as presented in Fig. 2. Therefore, lower $\beta$ in the winter might be attributed to the transport of sea-salt particles and hygroscopic growth. In contrast, higher $\beta$ was also observed in the winter (10 and 19 May, 28 June and 18 August) when air masses came from the free troposphere or from over Antarctic continent (Fig. 2). Less coarse particles in the free troposphere or inland area can engender high $\beta$ in such cases.

High aerosol enhancement was observed on 23 March, 28 May, 22 July and 30 September in this study. The number concentrations increased to ca. $18001^{-1}$ in $D_{p}>0.3 \mu \mathrm{m}$ and ca. $3151^{-1}$ in $D_{p}>2.0 \mu \mathrm{m}$ on 23 March when diamond dust was observed visually during the tethered balloon observation. The air mass on 23 March was transported from the boundary layer of mid-latitudes $\left(\leq 50^{\circ} \mathrm{S}\right)$ as presented in Fig. 2. Furthermore, higher relative humidity $(60-90 \%)$ was obtained in the lower free troposphere (Fig. 3). Considering the appearance of diamond dust, high aerosol enhancement on 23 March might be associated with poleward flow of the air mass with high aerosol concentration and a large amount of water vapour from mid-latitudes, and particle growth to diamond dust by condensation of water vapour onto aerosol particles during transport.

Because diamond dust was not observed in the other aerosol enhancement (28 May, 22 July and 30 September), aerosol concentration increased owing to the processes other than diamond dust. Aerosol enhancement on 28 May, 22 July and 30 September corresponded to periods during or immediately after "Antarctic haze" events recorded at Syowa Station (Hara et al., 2010). According to our previous work (Hara et al., 2010), air masses of "Antarctic haze" were transported from the mid-latitudes to Syowa Station. As presented in Fig. 3 b and c, vertical features suggest that the high aerosol concentration was extended not only to the boundary layer, but also to the lower free troposphere. For instance, the aerosol number concentration reached ca. $180001^{-1}$ in $D_{p}>0.3 \mu \mathrm{m}$ on 28 May and ca. $2501^{-1} D_{p}>2.0 \mu \mathrm{m}$ on 22 July. Although aerosol enhancement was observed only in the boundary layer on 22 July, aerosol enhancement was also recognized in the lower free troposphere on 28 May and 30 September. Airplane-borne aerosol measurements (Yamanouchi et al., 1999) and balloon-borne OPC measurement (Japan Meteorological Agency, 2006) also indicated the aerosol enhanced layer from near the ground to ca. $3000 \mathrm{~m}$ on 30 August 1997 and 18 June 2004. Consequently, the "Antarctic haze" layer might extend vertically to the lower free troposphere or appear in the free troposphere over Syowa Station. Although seasonal features of occurrence of Antarctic haze near surface were described by Hara et al. (2010), the appearance of the haze layer in the free troposphere and upper boundary layer remains poorly documented. Measurement of the aerosol vertical distribution is necessary to obtain more knowledge about the Antarctic haze in the future.

In contrast to the aerosol enhancement as described above, the number concentrations of fine and coarse particles were occasionally lower even in the winter, for example on 10 May, 19 May, 16 June and 28 June. The aerosol number concentration $\left(<3001^{-1}\right.$ in $D_{p}>0.3 \mu \mathrm{m}$ and $<61^{-1}$ in $\left.D_{p}>2.0 \mu \mathrm{m}\right)$ was two orders lower than the aerosol enhancement. Backward trajectory results suggest that air masses originated from the free troposphere over the Antarctic continent (Fig. 2). Here, it is noteworthy that the tethered balloon operation was restricted by surface wind conditions, so that the observation data in the present study were taken mostly in calm weather in high-pressure conditions. Continuous aerosol measurements at the surface (e.g., Hara et al., 2004, 2010) indicated that lower number concentrations were infrequent during winter-spring at Syowa Station.

\subsubsection{Seasonal and vertical features of $\mathrm{CN}$ concentration}

Figure 3e depicts seasonal and vertical features of $\mathrm{CN}$ concentration over Syowa Station. In the observed altitude (surface - ca. $2500 \mathrm{~m}$ ), the $\mathrm{CN}$ concentration showed clear seasonal features with a maximum in summer and minimum in winter. Range of $\mathrm{CN}$ concentration in the boundary layer was $19-3768 \mathrm{~cm}^{-3}$ (mean, $348 \mathrm{~cm}^{-3}$; median $204 \mathrm{~cm}^{-3}$ ). In contrast, $\mathrm{CN}$ concentration measured from ground-base $\mathrm{CN}$ measurements $\left(D_{p}>10 \mathrm{~nm}\right)$ in 2005 indicated range of 18$5766 \mathrm{~cm}^{-3}$ (mean, $403 \mathrm{~cm}^{-3}$; median $273 \mathrm{~cm}^{-3}$ ). Although the highest $\mathrm{CN}$ concentration in the ground-base measurements was larger than those in tethered balloon measurements, the difference might be caused by an increase of $\mathrm{CN}$ concentrations in the ground-base measurements during the storm conditions as shown in Hara et al. $(2010,2011)$ as well as variations of the number concentrations in fine and coarse 
modes (as mentioned above). The seasonal features, however, were similar to those of the $\mathrm{CN}$ variation at ground level of the Antarctic coasts (Ito et al., 1993; Gras et al., 1993). In end-January-March and mid-September, higher CN concentrations were observed in the free troposphere $(>1200 \mathrm{~m})$. The $\mathrm{CN}$-enhanced layer in the free troposphere was not obtained during the winter. Details of $\mathrm{CN}$-enhanced layer will be discussed in a later section (Sect. 3.3). Although the $\mathrm{CN}$ concentration was usually lower in the winter, a higher $\mathrm{CN}$ concentration was obtained in the winter when the air masses were transported from the Southern Ocean and the Antarctic coast (e.g., 28 May and 28 June). Considering that the $\mathrm{CN}$ concentration on the ground increased drastically to $>500 \mathrm{~cm}^{-3}$ even in the winter under the storm conditions (Hara et al., 2010), the higher $\mathrm{CN}$ concentration in the winter might be associated with (1) transport from the mid-latitudes because of a cyclone approach and (2) wind-blowing aerosol emission from the ocean surface and sea-ice. Indeed, aerosol enhancement after the storm conditions was observed occasionally at ground level (Hara et al., 2010) and in the free troposphere (Yamanouchi et al., 1999). Similar phenomenon was observed at Aboa station during the summer (Virkkula et al., 2007). More information related to aerosol properties such as the size distribution and chemical compositions must be obtained to elucidate the sources of $\mathrm{CN}$ during the winter.

Figure 4 depicts box plots of the $\mathrm{CN}$ concentration at each altitude. During tethered balloon borne measurements, the highest altitude of surface inversion layer reached $\approx 300 \mathrm{~m}$ (average, $180 \mathrm{~m}$ ), although the surface inversion layer was not observed in the summer. The height of boundary layer ranged between $420-1400 \mathrm{~m}$ and was mostly lower than $1000 \mathrm{~m}$ (average, $840 \mathrm{~m}$ ). Therefore, $\mathrm{CN}$ concentration in $>1500 \mathrm{~m}$ shows a seasonal feature in the free troposphere over Syowa. The CN concentration at the surface $-300 \mathrm{~m}$ varied by two orders $\left(30-2200 \mathrm{~cm}^{-3}\right)$ during the year, although it varied by three orders $\left(7-7250 \mathrm{~cm}^{-3}\right)$ at altitudes higher than $1500 \mathrm{~m}$. The $\mathrm{CN}$ concentration was not significantly different between surface inversion $(<300 \mathrm{~m})$ and boundary layer (300-650 $\mathrm{m}$ and $650-1000 \mathrm{~m}$ ). Surprisingly, the lowest $\mathrm{CN}$ concentration dropped to $<10 \mathrm{~cm}^{-3}$ in the free troposphere during the winter. The $\mathrm{CN}$ concentration in the boundary layer and surface inversion was higher than that in the free troposphere in the winter-spring. However, the $\mathrm{CN}$ concentration in the free troposphere was higher than that at the surface $-300 \mathrm{~m}$ in January-March and in September. As depicted in Fig. 3e, the vertical gradient is expected to result from the appearance of the $\mathrm{CN}$-enhanced layer in the free troposphere on 26 January, 12, 16 February, 14 March and 17 September. Air masses in the $\mathrm{CN}$-enhanced layer originated mostly from the Southern Ocean (see Fig. 2). Therefore, new particle formation was expected to take place in association with aerosol precursors derived from oceanic bioactivity.

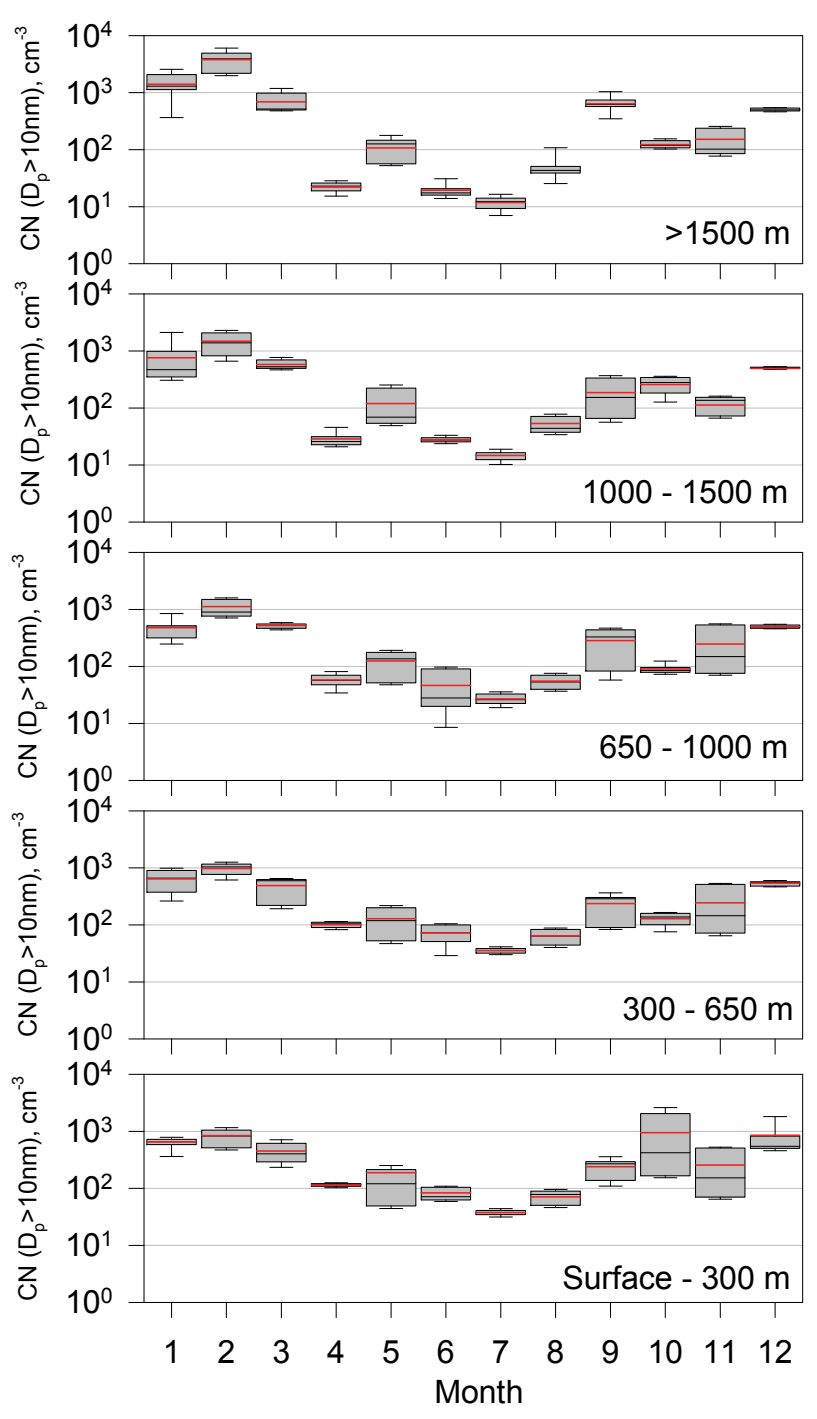

Fig. 4. Seasonal variation of $\mathrm{CN}$ concentration in each altitude. Top and bottom of the bar in box plots indicate 95 and $5 \%$ values. Top, middle and bottom of the box indicate 75, 50 (median), and $25 \%$ values. Red lines indicate monthly mean $\mathrm{CN}$ concentration.

\subsection{The CN-enhanced layer over Syowa Station}

Among the 27 tethered balloon observations conducted during the year, a $\mathrm{CN}$-enhanced layer in the free troposphere was obtained on 26 January, 12, 16 February, 14 March and 17 September. Figure 5 portrays the vertical distributions of aerosol number concentrations in the cases of appearance of $\mathrm{CN}$-enhanced layer. In general, the $\mathrm{CN}$ concentration was influenced considerably by local contamination. As described in Sect. 3.2.1, CN-enhanced layer in the free troposphere was unaffected by local contamination.

The CN-enhanced layer was observed frequently in January-mid-March and September during the observations. The CN concentration in the layer was $1400-7250 \mathrm{~cm}^{-3}$ in 

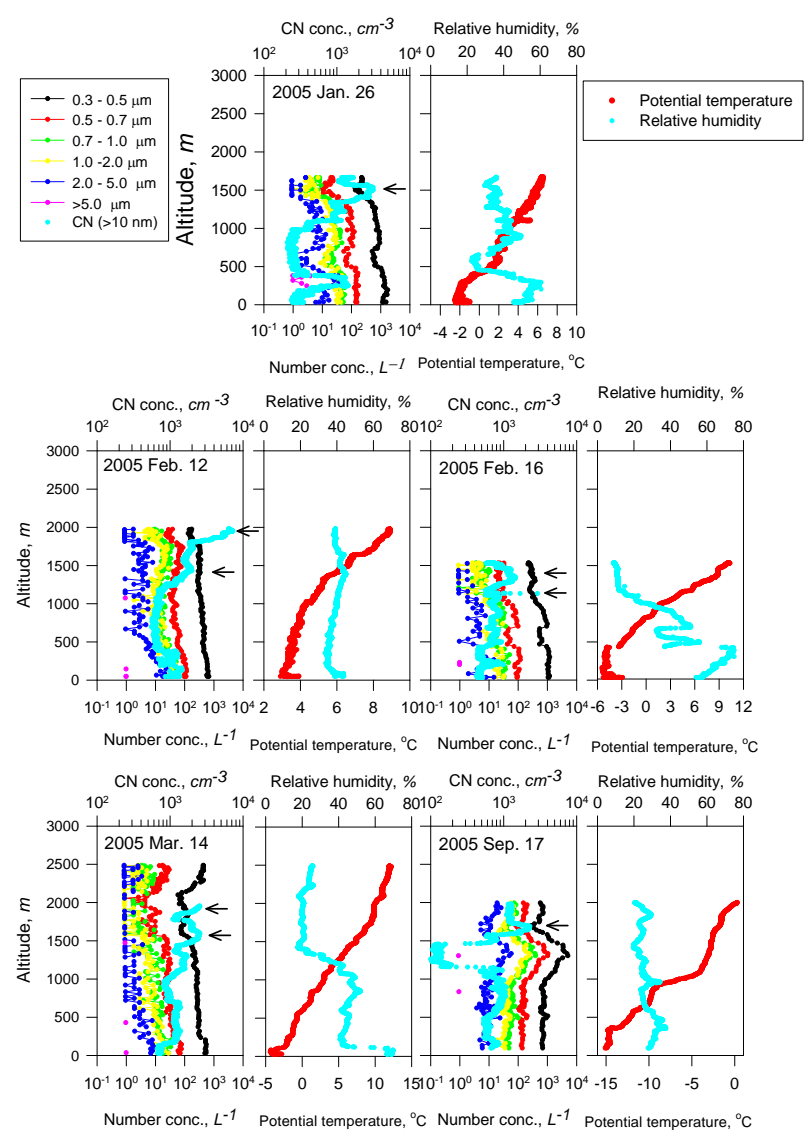

Fig. 5. Vertical distributions of the number concentration of aerosols, relative humidity and potential temperature in the case of appearance of CN-enhanced layer over Syowa Station.

2005. Furthermore, the aerosol number concentrations of pre-existing particles (fine and coarse particles) decreased clearly at the height of the $\mathrm{CN}$-enhanced layer. Although the $\mathrm{CN}$-enhanced layer was not identified from October until December in the present study, Osada et al. (2006) reported a CN-enhanced layer observed on 29 November 2004. The CN concentration increased by approximately $2900 \mathrm{~cm}^{-3}$ in the CN-enhanced layer of November 2004 (Osada et al., 2006). The $\mathrm{CN}$ concentration, surprisingly, reached more than $7000 \mathrm{~cm}^{-3}$ in the layer on 12 February. Continuous $\mathrm{CN}$ measurements $\left(D_{p}>10 \mathrm{~nm}\right)$ at ground level at Syowa Station showed that monthly median $\mathrm{CN}$ concentration was ca. $450 \mathrm{~cm}^{-3}$ in February 2005 and that most $\mathrm{CN}$ data (>90\%) was distributed less than $1000 \mathrm{~cm}^{-3}$ in February 2005 (Hayashi et al., 2010). Consequently, the CN concentration in the layer was several tens of times higher than that on the ground level at Syowa Station. The altitude of the CNenhanced layer was distributed mostly in the free troposphere with lower relative humidity $(<40 \%)$.

$\mathrm{CN}$-enhanced layers over Syowa Station were distributed in the lower free troposphere. According to a model esti- mation by Pirjola et al. (2000), new particle formation in a remote area, such as Antarctic regions, prefers to proceed in free troposphere with the lower number concentrations of pre-existing particles. Moreover, results of previous investigations suggested that lower relative humidity and strong solar radiation are favourable conditions for new particle formation (Boy and Kulmala, 2002; Vehkamäki et al., 2004; Hamed et al., 2007). The CN-enhanced layer over Syowa Station satisfied these conditions. Therefore, the layers are expected to be associated with new particle formation.

For new particle formation, an air mass with higher concentrations of aerosol precursors must be transported over Syowa Station. Results of previous investigations suggest that aerosol precursors (e.g., $\mathrm{H}_{2} \mathrm{SO}_{4}$ gas) in the Antarctic troposphere were derived from bioactivity in the ocean (Ito, 1993; Gras et al., 1993; Minikin et al., 1998). To discuss the air mass origin in the $\mathrm{CN}$-enhanced layer, the five-day backward trajectory was calculated as depicted in Fig. 6. Except for the case on 26 January, the air mass came from the marine boundary layer (16 February and 14 March) or lower free troposphere over the southern ocean $\left(52-60^{\circ} \mathrm{S}\right)$ prior 5 days. Osada et al. (2006) also presented similar air mass history in the case of the $\mathrm{CN}$-enhanced layer in November 2004. The air mass of $\mathrm{CN}$-enhanced layer on 26 January was located at Antarctic coasts on the prior five days. Eight-day backward trajectory, however, indicated a poleward flow from the Southern Ocean to the Antarctic coast for 26 January (not shown). Consequently, air masses of the $\mathrm{CN}$-enhanced layer might be transported from the Southern Ocean. In contrast, the air mass origin in November-December, when $\mathrm{CN}$ layer was not observed, was the free troposphere over Antarctic coasts and the Antarctic continent, except for the case on 5 December, as presented in Fig. 2. Although air masses came mostly from the Southern Ocean and Antarctic coasts as shown in Fig. 2 during the winter-early spring, the $\mathrm{CN}$-enhanced layer was not observed except 17 September. Consequently, the air mass history of $\mathrm{CN}$-enhanced layer suggests strongly the link between new particle formation and oceanic bioactivity. Plausible aerosol precursors and condensable vapours in the Antarctic coasts during the austral summer are $\mathrm{H}_{2} \mathrm{SO}_{4}$, dimethylsulfide (DMS), $\mathrm{CH}_{3} \mathrm{SO}_{3} \mathrm{H}$ (MSA) and organics, which are derived from biogenic activity in the ocean. Indeed, previous works presented that these concentrations were higher in the Antarctic coasts and the Southern Oceans during the summer (e.g., Eisele and Tanner, 1993; Jefferson et al., 1998a, b; Inomata et al., 2006; Eisele et al., 2008).

The CPC used for this study can measure the number concentration of $\mathrm{CN}$ larger than $10 \mathrm{~nm}$ in diameter. Therefore, new particles $\left(D_{p}<2 \mathrm{~nm}\right)$ must be grown up to $D_{p}>10 \mathrm{~nm}$ to be detected as a "CN-enhanced layer". With the suggestion of the backward trajectory (Fig. 6), the CN-enhanced layer must be formed within several days to one week from new particle formation, when new particle formation occurred in the Southern Ocean to the Antarctic coasts. Here, 


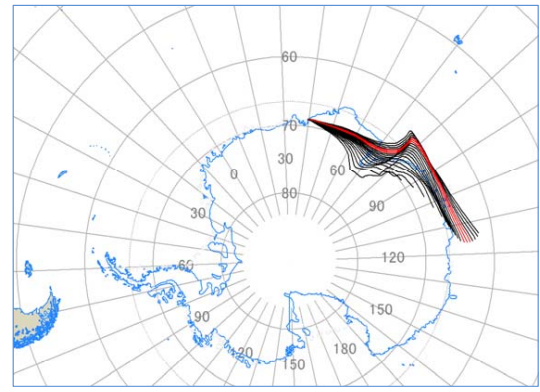

(a) $2005 \operatorname{Jan} 26$
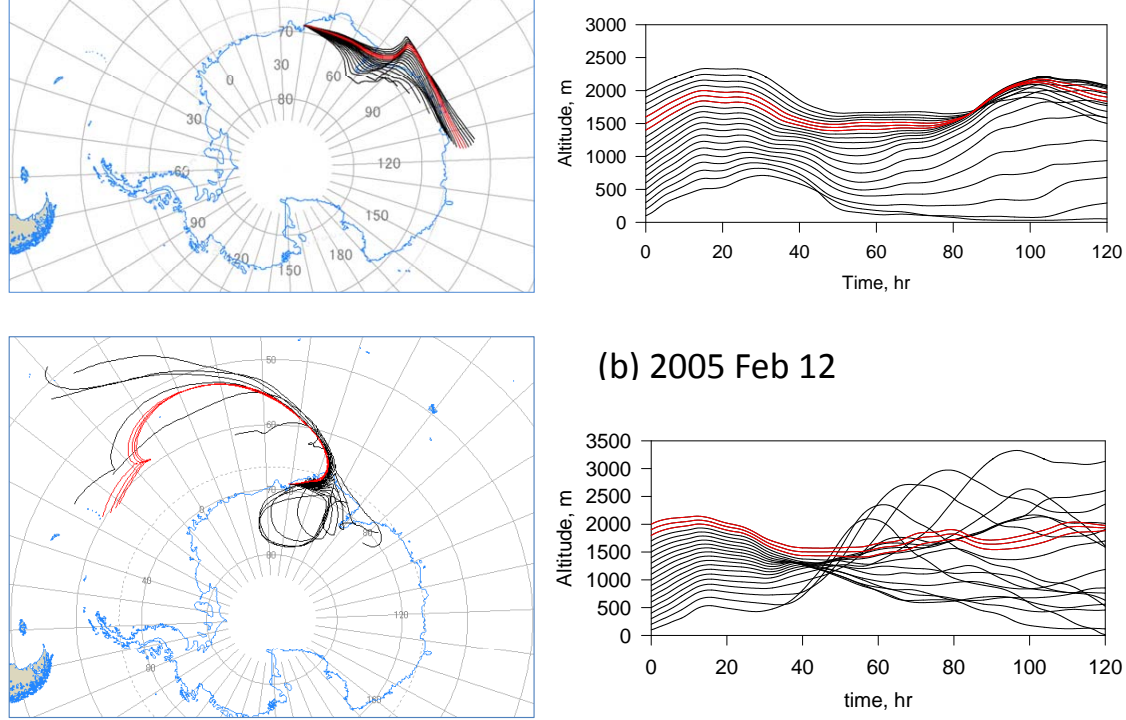

\section{(b) 2005 Feb 12}
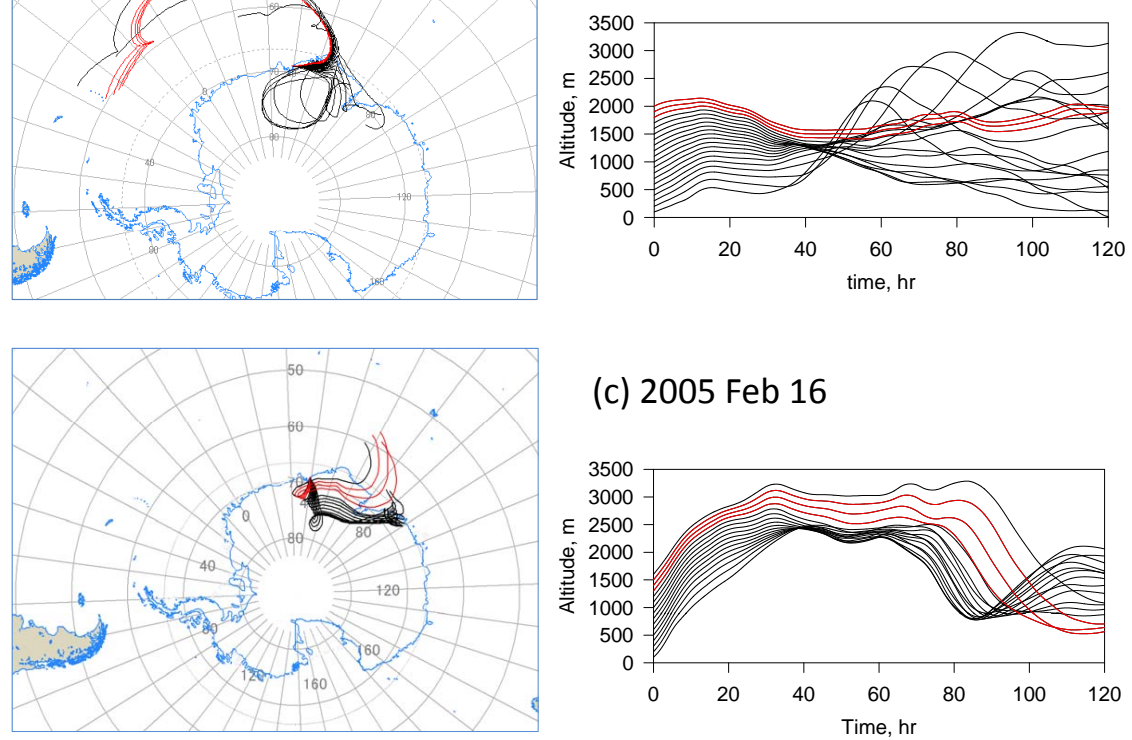

\section{(c) 2005 Feb 16}
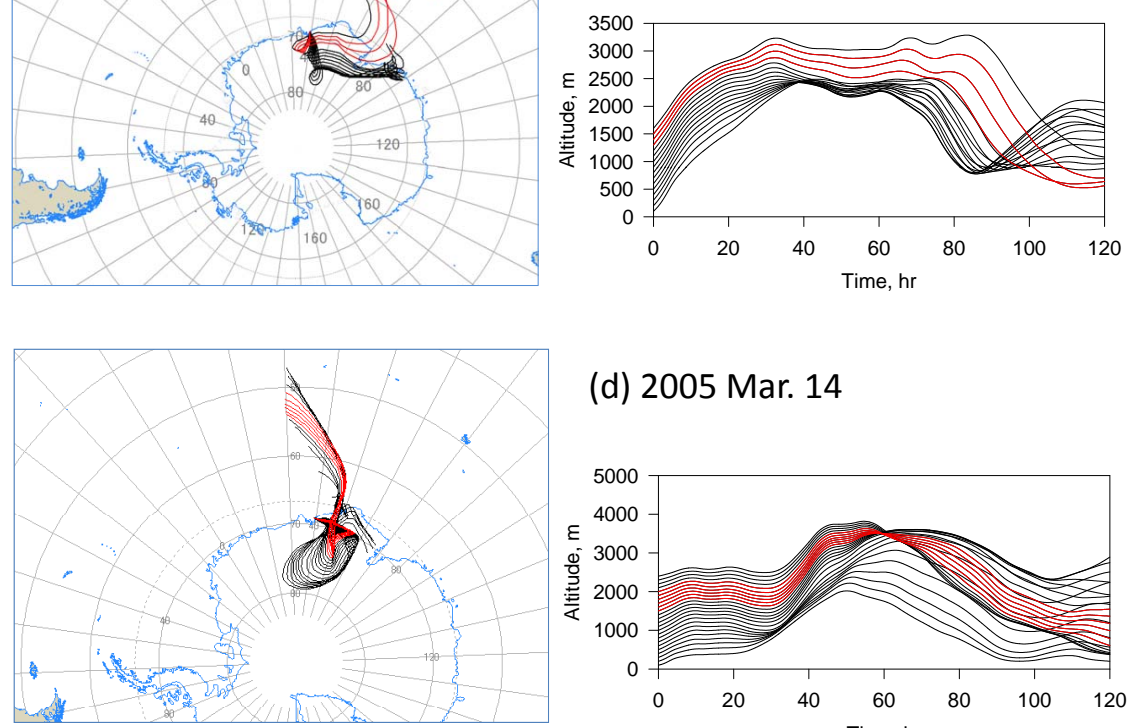

(d) 2005 Mar. 14
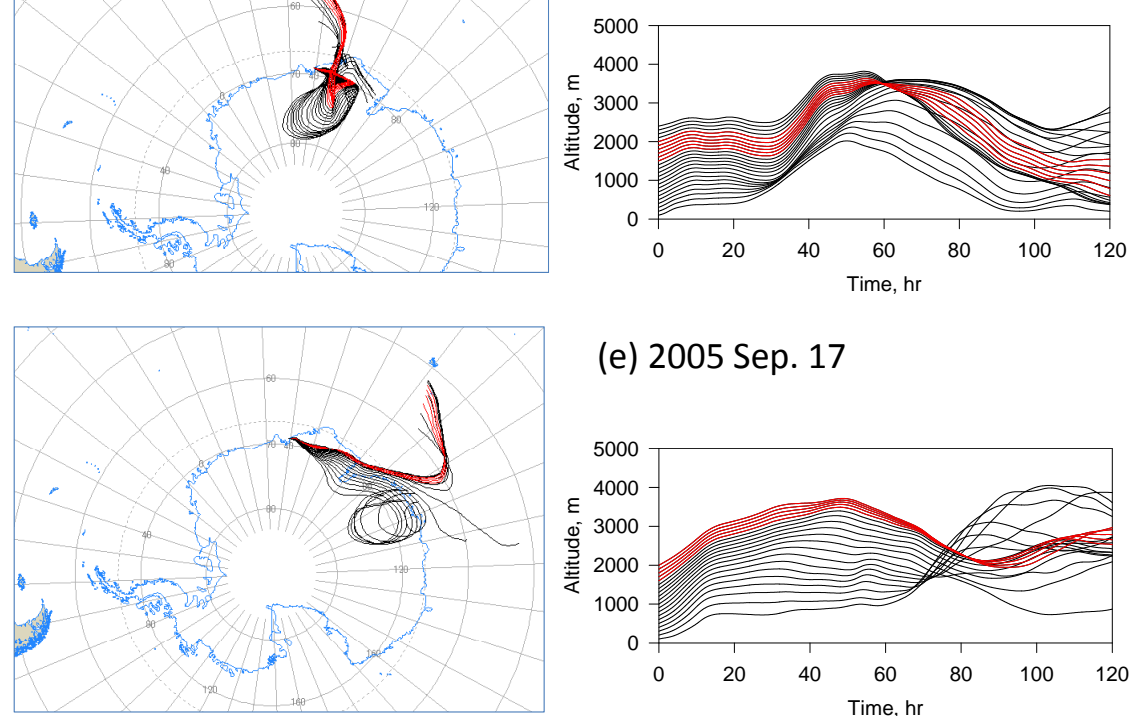

(e) 2005 Sep. 17

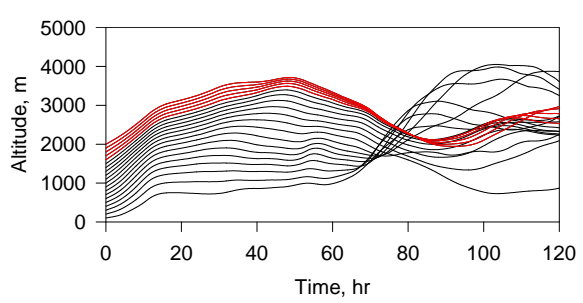

Fig. 6. 5-day backward trajectory in appearance of CN-enhanced layer: (a) 26 January, 2005, (b) 12 February, (c) 16 February, (d) 14 March, and (e) 17 September. Red lines represent the trajectory from CN-enhanced layer. 
we attempt to estimate the time for particle growth from new particles $\left(D_{p}=1 \mathrm{~nm}\right)$ to particles in nucleation mode $\left(D_{p}>10 \mathrm{~nm}\right)$. According to Kulmala et al. (2001), the growth-rate of aerosol particles in nucleation mode can be expressed as the following equation.

$\frac{d r}{d t}=\frac{m_{v} \beta_{m} D C}{r \rho}$.

In Eq. (2), $C, r, m_{v}, \beta_{m}, D$ and $\rho$, respectively, signify the concentration of condensable vapour, particle radius, molecular mass of condensable vapour, transitional correction factor for mass flux, diffusion coefficient, particle density. Equation (2) can be integrated from $r_{0}$ to $r$ to obtain

$C=\frac{\rho\left\{\frac{r^{2}-r_{0}^{2}}{2}\left(\frac{4}{3 \alpha}-0.623\right) \lambda^{2} \ln \left(\frac{\lambda+r}{\lambda+r_{0}}\right)\right\}}{\Delta t D m_{v}}$.

In Eq. (3), $\lambda$ represents the mean free path. In this study, we assume that the radius of new particle $\left(r_{0}\right)$ is $0.5 \mathrm{~nm}$. Previous aerosol measurements taken during the summer at the Antarctic coast showed that the important condensable vapours are $\mathrm{H}_{2} \mathrm{SO}_{4}$ and methanesulfonic acid (MSA) derived from oceanic bioactivity (Eisele and Tanner, 1993; Jefferson et al., 1998a, b; Eisele et al., 2008). Furthermore, recent works have shown that organic vapours can act as condensable vapours even in Antarctic troposphere (Meskhidze and Nenes, 2006; Asmi et al., 2010). In the present study, however, only $\mathrm{H}_{2} \mathrm{SO}_{4}$ and MSA are considered as "condensable vapours" because of a lack of knowledge (e.g., concentrations and compounds) about organic vapours in the Antarctic troposphere. Although $\alpha$ of $\mathrm{H}_{2} \mathrm{SO}_{4}$ and MSA is typically assumed to be unity, Eisele and Turner (1993) suggested $\alpha=0.5$ for the mass accommodation coefficient of $\mathrm{H}_{2} \mathrm{SO}_{4}$ from field observations. Here, the time for particle growth was estimated as $\alpha=0.5$ and $\alpha=1$. The air temperature of $253-273 \mathrm{~K}$ was used to calculate particle growth, assuming the condition of lower free troposphere in the summer Antarctic coast. Diffusion coefficients of $\mathrm{H}_{2} \mathrm{SO}_{4}$ and $\mathrm{CH}_{3} \mathrm{SO}_{3} \mathrm{H}$ were in accordance with those reported by Hansen and Eisele (2000) and Hansen (2005). We assumed that concentrations of the condensable vapours were constant during the particle growth from new particles $\left(D_{p}=1 \mathrm{~nm}\right)$ to particles with the size of $D_{p}=10 \mathrm{~nm}$ in this estimation.

Figure 7 presents the relation between the concentrations of condensable vapours and the time for particle growth to $D_{p}>10 \mathrm{~nm}$. The time for particle growth depends on air temperature, but not to a statistically significant degree. The mean free path can be larger in the upper atmosphere (lower air pressure). Therefore, a longer time was required for particle growth at the higher altitude. According to field measurements of the ambient concentrations of $\mathrm{H}_{2} \mathrm{SO}_{4}$ and MSA in the summer at Palmer Station (Jefferson et al., 1998a, b) and South Pole Station (Mauldin III et al., 2001, 2004; Eisele et al., 2008), the sum of their concentrations was $2 \times 10^{4}-2 \times$ $10^{7}$ mole $\mathrm{cm}^{-3}$. The time for particle growth is not a realistic

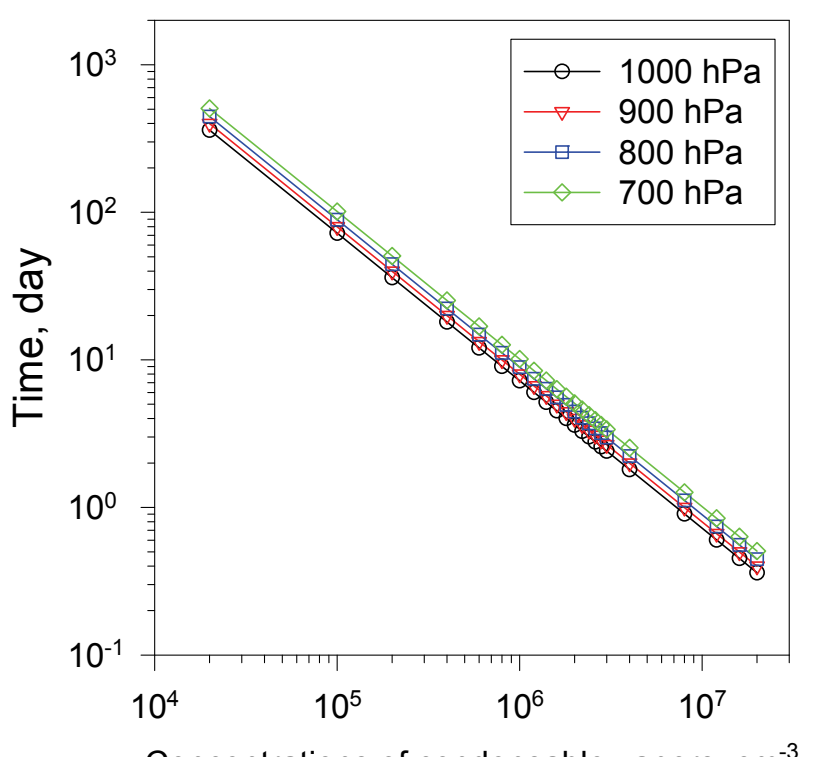

Fig. 7. Relationship between time to grow to $D_{p}>10 \mathrm{~nm}$ and concentration of condensable vapours in the case of $\alpha=1$.

value ( $>100$ days) when the concentrations of condensable vapours are in the order of $10^{4}$ mole $\mathrm{cm}^{-3}$. Under the conditions of mean vapour concentrations in Antarctic coasts during the summer $\left(\mathrm{H}_{2} \mathrm{SO}_{4}(\mathrm{~g}), 1.61 \times 10^{6} \mathrm{~mole}^{-3} ; \mathrm{MSA}(\mathrm{g})\right.$, $9.5 \times 10^{5} \mathrm{~mole}^{-3}$ ) (Jefferson et al., 1998a, b), the time for growth was estimated as approximately 4 days in $\alpha=1$ and $700 \mathrm{hPa}$ and 7 days in $\alpha=0.5$ and $700 \mathrm{hPa}$. These times were consistent with the transport time from the ocean, as estimated from the backward trajectory depicted in Fig. 6. Under conditions with the highest vapour concentrations (order of $10^{7} \mathrm{~mole} \mathrm{~cm}^{-3}$ ), new particles can grow to $D_{p}>10 \mathrm{~nm}$ within one day. The estimated time for particle growth was comparable with the growth rate in new particle formation $\left(0.1-3 \mathrm{~nm} \mathrm{~h}^{-1}\right)$ for the Antarctic coast (Koponen et al., 2003; Kulmala et al., 2004; Virkkula et al., 2007). When organic vapours contribute significantly to particle growth, as suggested by Meskhidze and Nenes (2006) and Asmi et al. (2010), the time for particle growth can be shorter relative to results in Fig. 7. Consequently, the $\mathrm{CN}$-enhanced layer might be formed by new particle formation around the Antarctic coast.

In year-round SMPS measurements at Syowa Station, new particle formation events (growth from $D_{p}<3 \mathrm{~nm}$ : typically known as "banana shaped") were observed only twice from January 2005 through December 2005 (unpublished data). In addition, no new particle formation event was detected in ship-borne SMPS measurements (R/V Tangaroa, Hakuhomaru, training vessel Umitaka-maru, and icebreaker Shirase) around the Antarctic coast to the Southern Ocean during the austral summer. Although nucleation modes were observed occasionally in the marine boundary layer (Osada et 
al., 2010b) as well as the ship-borne aerosol measurements by Koponen et al. (2002), the mode size was mostly larger than $10 \mathrm{~nm}$; marked particle growth (i.e., known as banana shaped) from new particles $\left(D_{p}<10 \mathrm{~nm}\right)$ was not observed at all during the measurements. Consequently, new particle formation around the Antarctic coast (e.g., Syowa Station) appears to occur frequently in the lower free troposphere, as depicted in Fig. 3, in contrast to fewer nucleation events occurring near the surface. Because the $\mathrm{CN}$-enhanced layer was observed already on 17 September, new particle formation can proceed in the lower free troposphere over Antarctic coasts even in mid-September when the following conditions are satisfied: (1) transport from the ocean with biogenic activity, and (2) strong solar radiation sufficient for photochemical oxidation of aerosol precursors. Indeed, the CN concentration on surface level at Syowa Station increased again from September (e.g., Ito et al., 1993; Hayashi et al., 2010). Also, Virkkula et al. (2009) suggested that new particle formation near surface at Aboa station was observed in the air mass originated from the upper atmosphere. Therefore, new particles forming in the free troposphere might be grown gradually and diffused in the Antarctic troposphere.

As presented in Fig. 5, number concentrations of preexisting particles dropped clearly in the $\mathrm{CN}$-enhanced layer in the lower free troposphere. Because aerosol precursors and condensable vapours were released dominantly from the ocean surface through the biogenic activity in the Antarctic coasts, the vapours must be lifted to the free troposphere for new particle formation in the $\mathrm{CN}$-enhanced layer. Indeed, high concentrations of DMS and DMSO, derived from oceanic bioactivity, were observed in the Antarctic coasts (Jourdain and Legrand, 2001; Legrand et al., 2001). In particular, Legrand et al. (2001) pointed out vertical transport of DMS and DMSO into the free troposphere during the summer. Vertical transport of air mass in the marine boundary layer, however, can engender higher concentrations of both aerosols (pre-existing particles) and aerosol precursors in the lower free troposphere, so that removal processes of aerosols might be necessary for favourable conditions for new particle formation in the $\mathrm{CN}$-enhanced layer. For better understanding of the relation between climate change and bioactivity in the ocean through atmospheric aerosols in Antarctic regions, more vertical observations of aerosols must be conducted in the sea-ice margin, oceans and glaciers (continent). In particular, more knowledge about (1) release of aerosol precursors from the ocean surface, (2) vertical transport processes of the precursors into free troposphere, and (3) occurrence of new particle formation in the lower free troposphere and the boundary layer must be obtained to support quantitative estimation of new particle formation in Antarctic regions.

\section{Conclusions}

Tethered balloon-borne aerosol measurements were conducted at Syowa Station, Antarctica throughout the year in 2005. Aerosol number concentrations in fine $\left(D_{p}>0.3 \mu \mathrm{m}\right)$ and coarse particles $\left(D_{p}>2.0 \mu \mathrm{m}\right)$ were lower in the summer and higher in the winter over Syowa Station. Higher aerosol number concentrations were observed in air masses transported from the Antarctic coast and the Southern Ocean during the winter, although the number concentrations decreased in the air masses over the Antarctic continent. Consequently, aerosol emissions from the surfaces of ocean and sea-ice through wind blowing processes might cause aerosol enhancement in fine and coarse modes in the Antarctic coasts during winter-spring. Aerosol enhancement was observed occasionally not only in the boundary layer, but also in the lower free troposphere during Antarctic haze phenomena. Vertical aerosol measurements (especially in the free troposphere) are necessary for better understanding of Antarctic haze (e.g., transport processes, climate impact and contribution to atmospheric chemistry). In addition, size distributions of fine-coarse particles showed clear seasonal features. Variation of Junge's slope implied that coarse particles were enhanced because of the release of wind-blowing particles during winter-spring, although fine particles were enhanced during the summer.

Near the surface, $\mathrm{CN}$ concentrations were $30-2200 \mathrm{~cm}^{-3}$, but they were $7-7250 \mathrm{~cm}^{-3}$ in the lower free troposphere $(>1500 \mathrm{~m})$. Seasonal variation of the $\mathrm{CN}$ concentration showed a maximum in the summer and minimum in winter in lower troposphere. Similar to the variation of the number concentration of fine and coarse particles, the CN concentration increased in air masses transported from the Antarctic coasts and Southern Ocean in the winter-spring. During the summer, the $\mathrm{CN}$-enhanced layer often appeared in the lower free troposphere where the number concentrations of pre-existing particles decreased markedly. Air masses of the $\mathrm{CN}$-enhanced layer were transported mostly from the Southern Ocean within 5 days. Estimation of particle growth suggested that the $\mathrm{CN}$-enhanced layer was formed by new particle formation in the free troposphere. Considering less frequent events of new particle formation near surface at Syowa Station (twice a year in 2005) and at the Southern Ocean - Antarctic coast, new particle formation might be more likely to occur in the lower free troposphere of the Antarctic coasts. More information about vertical distributions of aerosols over Antarctic coasts is necessary to elucidate them.

Acknowledgements. We would like to thank K. Matsubara (JARE46 leader), and K. Watanabe (JARE46 wintering leader; NIPR) for useful comments to field operation around Syowa Station. Furthermore, we are grateful to T. Sato, H. Nishimaki, H. Yamamoto, T. Iwaki, D. Ito, S. Tasaka, A. Furusaki, M. Igarashi, T. Uemura, T. Okudaira, Y. Hasegawa, T. Yamazaki, H. Mizobuchi, M. Ikeda, K. Egawa, H. Takahashi, I. Okabayashi, E. Kishimoto for help with tethered balloon operation under severe conditions, 
and to A. Yukimatsu, T. Matsumoto, M. Shuto, Y. Takagi, M. Kobayashi, H. Hamamoto, K. Harada, J. Fujii, K. Harigae, and Y. Ohmi for help with logistic work. Training of tethered balloon operation was conducted at the aerological observatory at Tsukuba, Japan through cooperation with Y. Shuto (JMA), and T. Kimura (aerological observatory), who also provided useful and helpful comments related to tethered balloon operation. Useful comments for balloon operations in Antarctic regions were also offered by N. Hirasawa (NIPR) and K. Sato (Univ. of Tokyo). We thank A. Virkkula (Referee) and an anonymous referee for helpful and useful comments to improve our paper. The authors gratefully acknowledge the NOAA Air Resources Laboratory (ARL) for provision of the HYSPLIT transport and dispersion model and the READY website (http://www.arl.noaa.gov/ready.html) used in this publication.

Edited by: R. Krejci

\section{References}

Asmi, E., Frey, A., Virkkula, A., Ehn, M., Manninen, H. E., Timonen, H., Tolonen-Kivimäki, O., Aurela, M., Hillamo, R., and Kulmala, M.: Hygroscopicity and chemical composition of Antarctic sub-micrometre aerosol particles and observations of new particle formation, Atmos. Chem. Phys., 10, 4253-4271, doi:10.5194/acp-10-4253-2010, 2010.

Ayers, G. P. and Cainey, J. M.: The CLAW hypothesis: a review of the major developments, Environ. Chem., 4, 366-374. doi:10.1071/EN07080, 2007.

Bodhaine, B. A.: Aerosol absorption measurements at Barrow, Mauna Loa and the South Pole, J. Geophys. Res., 100, 89678975, 1995.

Boy, M. and Kulmala, M.: Nucleation events in the continental boundary layer: Influence of physical and meteorological parameters, Atmos. Chem. Phys., 2, 1-16, doi:10.5194/acp-2-1-2002, 2002.

Charlson, R., Lovelock, J., Andreae, M., and Warren, S.: Oceanic phytoplankton, atmospheric sulphur, cloud albedo and climate, Nature, 326, 655-661, doi:10.1038/326655A0, 1987.

Draxler, R. R. and Rolph, G. D.: HYSPLIT (HYbrid Single-Particle Lagrangian Integrated Trajectory) Model access via NOAA ARL READY Website (http://ready.arl.noaa.gov/HYSPLIT. php), NOAA Air Resources Laboratory, Silver Spring, MD, 2011.

Eisele, F. and Tanner, D.: Measurement of the gas phase concentration of $\mathrm{H}_{2} \mathrm{SO}_{4}$ and methane sulfonic acid and estimates of $\mathrm{H}_{2} \mathrm{SO}_{4}$ production and loss in the atmosphere, J. Geophys. Res., 98(D5), 9001-9010, 1993.

Eisele, F., Davis, D. D., Helmig, D., Oltmans, S. J., Neff, W., Huey, G., Tanner, D., Chen, G., Crawford, J., Arimoto, R., Buhr, M., Mauldin, L., Hutterli, M., Dibb, J., Blake, D., Brooks, S. B., Johnson, B., Roberts, J. M., Wang, Y., Tan, D. and Flocke, F.: Antarctic Tropospheric Chemistry Investigation (ANTCI) 2003 overview, Atmos. Environ., 42, 2749-2761, 2008.

Fiebig, M., Lunder, C. R., and Stohl, A.: Tracing biomass burning aerosol from South America to Troll Research Station, Antarctica, Geophys. Res. Lett., 36, L14815, doi:10.1029/2009GL038531, 2009.
Gras, J. L.: Condensation nucleus size distribution at Mawson, Antarctica: seasonal cycle, Atmos. Environ., 27, 1417-1425, 1993.

Hamed, A., Joutsensaari, J., Mikkonen, S., Sogacheva, L., Dal Maso, M., Kulmala, M., Cavalli, F., Fuzzi, S., Facchini, M. C., Decesari, S., Mircea, M., Lehtinen, K. E. J., and Laaksonen, A.: Nucleation and growth of new particles in Po Valley, Italy, Atmos. Chem. Phys., 7, 355-376, doi:10.5194/acp-7-355-2007, 2007.

Hara, K., Osada, K., Kido, M., Hayashi, M., Matsunaga, K., Iwasaka, Y., Yamanouchi, T., Hashida, G., and Fukatsu, T.: Chemistry of sea-salt particles and inorganic halogen species in Antarctic regions: Compositional differences between coastal and inland stations, J. Geophys. Res., 109, D20208, doi:10.1029/2004JD004713, 2004.

Hara, K., Osada, K., Kido, M., Matsunaga, K., Iwasaka, Y., and Hashida, G.: Seasonal variations of sea-salt constituents and seasalt modification at Syowa Station, Antarctica, Tellus, 57B, 230 246, 2005.

Hara, K., Iwasaka, Y., Wada, M., Ihara, T., Shiba, H., Osada, K., and Yamanouchi, T.: Aerosol constituents and their spatial distribution in the free troposphere of coastal Antarctic regions, J. Geophys. Res., 111, D15216, doi:10.1029/2005JD006591, 2006.

Hara, K., Osada, K., Yabuki1, M., Hashida, G., Yamanouchi, T., Hayashi, M., Shiobara, M., Nishita-Hara, C., and Wada, M.: Haze episodes at Syowa Station, coastal Antarctica: Where did they come from?, J. Geophys. Res., 115, D14205, doi:10.1029/2009JD012582, 2010.

Hara, K., Osada, K., Nishita-Hara, C., Yabuki, M., Hayashi, M., Yamanouchi, T., Wada, M., and Shiobara, M.: Seasonal features of ultrafine particle volatility in the coastal Antarctic troposphere, Atmos. Chem. Phys. Discuss., 11, 14777-14799, doi:10.5194/acpd-11-14777-2011, 2011.

Hayashi, M.: Size distribution of aerosol in the stratosphere and troposphere observed with air-borne optical particle counter, Earozoru Kenkyu, 16, 118-124, 2001 (in Japanese).

Hayashi, M., Osada, K., Hara, K., Yabuki, M., Kobayashi, H., Ihara, S., Wada, M., Yamanouchi, T., Hashida, G., and Shiobara, M.: Monitoring of aerosol concentration at Syowa Station, Antarctic Record, 54, 474-486, 2010 (in Japanese with English abstract).

Iizuka, Y., Fujii, Y., Hirasawa, N., Suzuki, T., Motoyama, H., Furukawa, T., and Hondoh T.: $\mathrm{SO}_{4}^{2-}$ minimum in summer snow layer at Dome Fuji, Antarctica and the probable mechanism, J. Geophys. Res., 109, D04307, doi:10.1029/2003JD004138, 2004.

Inomata, Y., Hayashi, M., Osada, K., and Iwasaka, Y.: Spatial distributions of volatile sulfur compounds in surface seawater and overlying atmosphere in the northwestern Pacific Ocean, eastern Indian Ocean, and Southern Ocean, Global Biogeochem. Cy., 20, GB2022, doi:10.1029/2005GB002518, 2006.

Intergovernmental Panel on Climate Change, Climate Change 2007: The Physical Science Basis, edited by: Solomon, S., Qin, D., Manning, M., Chen, Z., Marquis, M., Averyt, K. B., Tignor, M., and Miller, H. L., Cambridge Univ. Press, New York, 2007.

Ito, T.: Antarctic Submicron Aerosols and Long-Range Transport of Pollutants, Ambio, 18, 34-41, 1989.

Ito, T.: Size distribution of Antarctic submicron aerosols, Tellus, 45B, 145-159, doi:10.1034/j.1600-0889.1993.t01-1-00007.x, 1993.

Ito, T., Morita, Y., and Iwasaka, Y.: Balloon observation of aerosols 
in the Antarctic troposphere and stratosphere, Tellus, 38B, 214222, 1986.

Iwasaka, Y., Okada, K., and Ono A.: Individual aerosol particles in the Antarctic upper troposphere, Mem. Natl. Inst. Polar Res. Spec. Issue, 39, 17-29, 1985.

Japan Meteorological Agency, Antarctic meteorological data (CDROM), Vol. 45 obtained using the 45th Japanese Antarctic research expedition at Syowa Station and Dome Fuji Station in 2004, 2006.

Jefferson, A., Tanner, D., Eisele, F., and Berresheim, H.: Sources and sinks of $\mathrm{H}_{2} \mathrm{SO}_{4}$ in the remote Antarctic marine boundary layer, J. Geophys. Res., 103(D1), 1639-1645, 1998a.

Jefferson, A., Tanner, D., Eisele, F., Davis, D., Chen, G., Crawford, J., Huey, J., Torres, A., and Berresheim, H.: OH photochemistry and methane sulfonic acid formation in the coastal Antarctic boundary layer, J. Geophys. Res., 103(D1), 1647-1656, 1998 b.

Jourdain, B. and Legrand, M.: Seasonal variations of atmospheric dimethylsulfide, dimethylsulfoxide, sulfur dioxide, methanesulfonate, and non-sea-salt sulfate aerosols at Dumont d'Urville (coastal Antarctica) (December 1998 to July 1999), J. Geophys. Res., 106(D13), 14391-14408, 2001.

Jourdain, B., Preunkert, S., Cerri, O., Castebrunet, H., Udisti, R., and Legrand, M.: Year-round record of size segregated aerosol composition in central Antarctica (Concordia station): Implications for the degree of fractionation of sea-salt particles, J. Geophys. Res., 113, D14308, doi:10.1029/2007JD009584, 2008.

Junge, C. E.: Aerosols in "Air chemistry and radioactivity" Academic Press., 111-208, 1963.

Kaufmann, P., Fundel, F., Fischer, H., Bigler, M., Ruth, U., Udisti, R., Hansson, M., de Angelis, M., Barbante, C. Wolff, E. W., Hutterli, M., and Wagenbach, D.: Ammonium and non-sea salt sulfate in the EPICA ice cores as indicator of biological activity in the Southern Ocean, Quaternary Sci. Rev., 29, 313-323, 2010.

Koponen, I. K., Virkkula, A., Hillamo, R., Kerminen, V.-M., and Kulmala, M.: Number size distributions and concentrations of marine aerosols: Observations during a cruise between the English Channel and the coast of Antarctica, J. Geophys. Res., 107(D24), 4753, doi:10.1029/2002JD002533, 2002.

Koponen, I. K., Virkkula, A., Hillamo, R., Kerminen, V. M., and Kulmala, M.: Number size distributions and concentrations of the continental summer aerosols in Queen Maud Land, Antarctica, J. Geophys. Res., 108(D18), 4587, doi:10.1029/2003JD003614, 2003.

Kulmala, M., Dal maso, M., Mäkelä, J. M., Pirjola, L., Väkevä, M., Aalto, P., Miikkulainen, P., Hämeri, K., and O’Dowd, C. D.: On the formation, growth and composition of nucleation mode particles, Tellus, 53B, 479-490, 2001.

Kulmala, M., Vehkamäki, H., Petäjä, T., Dal Maso, M., Lauri, A., Kerminen, V.-M., Birmili, W., and McMurry, P. H.: Formation and growth rates of ultrafine atmospheric particles: a review of observations, J. Aerosol. Sci., 35, 143-176, 2004.

Legrand, M. and Mayewski, P.: Glaciochemistry of polar ice cores: a review, Rev. Geophys., 35, 219-243, 1997.

Legrand, M., Sciare, J., Jourdain, B., and Genthon, C.: Subdaily variations of atmospheric dimethylsulfide, dimethylsulfoxide, methanesulfonate, and non-sea-salt sulfate aerosols in the atmospheric boundary layer at Dumont d'Urville (coastal Antarctica) during summer, J. Geophys. Res., 106(D13), 14409-14422, 2001.
Mauldin III, R. L., Eisele, F. L., Tanner, D. J., Kosciuch, E., Shetter, R., Lefer, B., Hall, S. R., Nowak, J. B., Buhr, M., Chen, G., Wang, P., and Davis, D.: Measurements of $\mathrm{OH}, \mathrm{H}_{2} \mathrm{SO}_{4}$, and MSA at the South Pole during ISCAT, Geophys. Res. Lett., 28(19), 3629-3632, 2001.

Meskhidze, N. and Nenes, A.: Phytoplankton and Cloudiness in the Southern Ocean, Science, 314, 1419-1423, 2006.

Minikin, A., Legrand, M., Hall, J., Wagenbach, D., Kleefeld, C., Wolff, E., Pasteur, E., and Ducroz, F.: Sulfur containing species (sulfate and methanesulfonate) in coastal Antarctic aerosol and precipitation, J. Geophys. Res., 103(D9), 10975-10990, 1998.

Osada, K., Hayashi, M., Ui, H., and Iwasaka, Y.: Ionic constituents in aerosol particles at Syowa Station, East Antarctica, during 1996, Polar Meteorology Glaciology, 12, 49-57, 1998.

Osada, K., Hara, K., Wada, M., Yamanouchi, T., and Matsunaga, K.: Vertical distribution of atmospheric aerosol particles over Syowa Station, East Antarctica: Airborne observations from spring to summer in 2004, Polar Meteorol. Glaciol., 20, 16-27, 2006.

Osada, K., Hayashi, M., Hara, K., Yabuki, M., Wada, M., Shiobara, M., Yamanouchi, T., and Fujita, K.: Seasonal variation of coarse aerosol particle concentration at Syowa station, Antarctica, Antarctic Record, 54, 487-497, 2010a (in Japanese with English abstract).

Osada, K., Hara, K., Yabuki, M., Nishita, C., Kobayashi, H., Miura, K., Ueda, S., Hayashi, M., Hashida, G., Shiobara, M., Wada, M., and Yamanouchi, T.: Observations of atmospheric aerosol particles over the Antarctic Ocean by ocean research vessels, Antarctic Record, 54, 449-464, 2010b (in Japanese with English abstract).

Pirjola, L., O’Dowd, C., Brooks, I., and Kulmala, M.: Can new particle formation occur in the clean marine boundary layer?, J. Geophys. Res., 105(D21), 26531-26546, 2000.

Rankin, A. M. and Wolff, E. W.: Aerosol Profiling Using a Tethered Balloon in Coastal Antarctica, J. Atmos. Ocean. Technol., 19, 1978-1985, 2002.

Rankin, A. M. and Wolff, E. W.: A year-long record of sizesegregated aerosol composition at Halley, Antarctica, J. Geophys. Res., 108(D24), 4775, doi:10.1029/2003JD003993, 2003.

Sato, K. and Hirasawa, N.: Statistics of Antarctic surface meteorology based on hourly data in 1957-2007 at Syowa Station, Polar Sci., 1, 1-15, 2007.

Savoie, D. L., Prospero, J. M., Larsen, R. J., and Saltzman, E. S.: Nitrogen and sulfur species in aerosols at Mawson, Antarctica, and their relationship to natural radionuclides, J. Atmos. Chem., 14, 181-204, 1992.

Savoie, D. L., Prospero, J. M., Larsen, R. J., Huang, F., Izaguirre, M. A., Huang, T., Snowdon, T. H., Custals, L., and Sanderson, C. G.: Nitrogen and sulfur species in Antarctic aerosols at Mawson, Palmer Station, and Marsh (King George Island), J. Atmos. Chem., 17, 95-122, 1993.

Shaw, G.: Bio-controlled thermostasis involving the sulfur cycles, Climatic Change, 5, 297-303, 1983.

Vehkamäki, H., Dal Maso, M., Hussein, T., Flanagan, R., Hyvärinen, A., Lauros, J., Merikanto, P., Mönkkönen, M., Pihlatie, K., Salminen, K., Sogacheva, L., Thum, T., Ruuskanen, T. M., Keronen, P., Aalto, P. P., Hari, P., Lehtinen, K. E. J., Rannik, Ü., and Kulmala, M.: Atmospheric particle formation events at Värriö measurement station in Finnish Lapland 1998-2002, At- 
mos. Chem. Phys., 4, 2015-2023, doi:10.5194/acp-4-2015-2004, 2004.

Virkkula, A., Hirsikko, A., Vana, M., Aalto, P. P., Hillamo, R., and Kulmala, M.: Charged particle size distributions and analysis of particle formation events at the Finnish Antarctic research station Aboa, Boreal Environ. Res., 12, 397-408, 2007.

Virkkula, A., Asmi, E., Teinilä, K., Frey, A., Aurela, M., Timonen, H., Mäkelä, T., Samuli, A., Hillamo, R., Aalto, P. P., Kirkwood, S., and Kulmala, M.: Review of Aerosol Research at the Finnish Antarctic Research Station Aboa and its Surroundings in Queen Maud Land, Antarc-tica, Geophysica, 45, 163-181, 2009.

Wada, M., Ihara, T., and Shiba, H.: Aerological and aerosol observations in the lower atmosphere using aircraft by the $41 \mathrm{st}$ Japanese Antarctic Research Expedition, 2000-2001, Antarctic Rec., 45, 257-278, 2001 (in Japanese with English abstract).

Watanabe, O., Kamiyama, K., Motoyama, H., Fujii, Y., Igarashi, M., Furukawa, T., Goto-Azuma, K., Saito, T., Kanamori, S., Kanamori, N., and Yoshida, N.: General tendencies of stable isotopes and major chemical constituents of the Dome Fuji deep ice core, Mem. Natl Inst. Polar Res., Spec. Issue, 57, 1-24, 2003.
Wagenbach, D., Ducroz, F., Mulvaney, R., Keck, L., Minikin, A., Legrand, M. J., Hall, S., and Wolff, E. W.: Sea-salt aerosol in coastal Antarctic regions, J. Geophys. Res., 103(D9), 1096110974, 1998.

Weller, R. and Wagenbach, D.: Year-round chemical aerosol records in continental Antarctica obtained by automatic samplings, Tellus, 59B, 755-765, 2007.

Wolff, E. W. and Cachier, H.: Concentrations and seasonal cycle of black carbon in aerosol at a coastal Antarctic station, J. Geophys. Res., 103(D9), 11033-11041, 1998.

Yamanouchi, T., Wada, M., Fukatsu, T., Hayashi, M., Osada, K., Nagatani, M., Nakata, A., and Iwasaka, Y.: Airborne observation of water vapour and aerosols along Mizuho route, Antarctica, Polar Meteorol. Glaciol., 13, 22-37, 1999.

Yamazaki, K., Okada, K., and Iwasaka, Y.: Where Do Aerosol Particles in the Antarctic Upper Troposphere Come From? - A Case Study in January 1983, J. Meteor. Soc. Japan, 67, 889-906, 1989. 